\title{
CREATION PROCESS OF PAINTING POOR WOMEN USING PHOTO REALISM TECHNIQUE
}

\author{
Anna Susilowati \\ Indonesian Institute of the Arts Surakarta, Indonesia.
}

\begin{abstract}
Not many painters create paintings in poverty-theme since they are considered unattractive and unfavourable by collectors. In contrast, this study conducted a research on poor people in Tebet Subdistrict to be painting objects. Tebet Subdistrict is a beautiful green and clean inhabited mostly by middle and upper class community. However, on the sidelines of the subdistrict were found poor people who work in the informal stor, such as rag pickers, buskers, unofficial parking attendants, housemaids, newspaper sellers and beggars. This study focused on portrayals in which female as the subject due to the fact that taking photographs and interviewing women were much more difficult. Women own a higher insecurity level to strangers than that of male informal workers. In creating a painting about poor women, the writer used photo realism style.
\end{abstract}

Keywords: Photo, Poor, Poverty, Realism, Women

\section{INTRODUCTION}

Tebet is a sub district area located in the southern part of Jakarta, the capital city of Indonesia. The environment in this sub-district is mostly neat, clean, has many beautiful and wellmaintained parks. In addition, the majority population of this sub-districts is middle to upper economy class. However, on the sidelines of this harmonious Tebet's environment, there is another life whose community where women work in many informal sectors. They are usually rag pickers or waste pickers from landfills, buskers, newspaper sellers, beggars, unofficial parking attendants and house servants. Many of their lives are miserable and unnoticed. Moreover, many of them are in poor condition, old aged and some have physical disabilities. From the interview conducted by the author, there was a woman who did three jobs a day, as a housemaid in the morning, a parking attendant during the day and a beggar at night, to fulfill her daily needs along with her three children's. Moreover, the author writer found a poor woman who always brought her daughter with Down syndrome to accompany her to work as a rag picker, where the daughter should go to school for children with special needs. This women's lack situation and the frequent meeting with them on the streets have sparked an idea to the 
International Journal of Arts and Humanities

ISSN: 2581-3102

Volume: 04, Issue: 04 "April 2020"

author to make their lives as objects of paintings creation. It was expected that the results of the paintings creation could arouse and remind the public that there are still many lower class people living in poverty and completely lacking everything who need to be helped.

Poor women were chosen as objects because the level of difficulty was greater besides the challenge in painting women was much higher than painting men. It was in fact difficult to approach women due to their shyness and self-esteem culture. Since the first meeting, they were very difficult to photograph. Thus, the method used to approach them was by using a highresolution cell phone camera, not a professional one, so they wouldn't feel worry. In interview research, the author did not do recording and noting to make them not afraid because they were suspicious of Government agents who liked to record their data and arrest those who did not have an identity card. This was different from male informal sector workers who were mostly easier to be approached. This condition might occur due to genders inequality problems and unequal treatment of men and women in earning money. The fact that there were a large number of women working in informal sector was due to high unemployment rate and their conditions were typically unskilled labors aside from the failure of the Government to improve the lives quality of the poor. This was reflected by the still high Gini ratio. It means large inequalities still widely occurred in the society. Hence, the lives of poor women was very important and necessary to be made into painting art works.

Discussion about poor women cannot be separated from its problem roots, i.e. economic problems. In short, poverty can be defined as a low standard of living: i.e. there is a level of material deprivation in a number or groups of people compared to the general standard of living in the society. This low standard of living has a direct effect on the levels of health, moral life, and self-esteem of those classified as the poor [1]. This declined self-esteem is due to the fact that they are also alienated and ignored from their own society. Moreover, they are a small number of people whose lives are neglected from the majority of society in general. This ignorance can occur, besides because the other people do not care, they are almost unseen because they mostly live in an isolated area, whose location is not easily seen in daily life. They do not clearly exist on the map even Google Maps does not show them. Those poor women live in blankspot marked in blue circle on the map as seen in Fig. 1, without any information, directions, coordinates, and without description since it is not defined. They are liyan (others). 'Liyan' (Others) based on Levinas' definition are 'not us'; they are foreigners, entities that are outside of us [2]. If they are from the outside, we will not see where they live because it is covered by mounds.

However, when you are willing to enter and pierce the mound, you will be able to see life there; people who are sleeping in used carts or mattresses, resting, cooking, and bathing from the 
gutters which cross the area. Oscar Lewis defined poverty with the characteristics described above in the term of 'Culture of Poverty'. According to Lewis, Culture of Poverty occurs because there are at least 5 conditions, i.e. (1) System of monetary economy, wage labor and production systems to make profits, (2) The high level of unemployment and underemployment for unskilled labor, (3) Low labor costs, (4) The failure of low-income groups to enhance their social, economic and socio-political organization both voluntarily or based on government initiatives, and (5) the Strength of a set of values in the class whose power which emphasizes the accumulation of wealth and the existing possibility of vertical mobility, economical attitude, as well as the assumption that the low economic status is a result of personal inability or because they are basically already low in position.

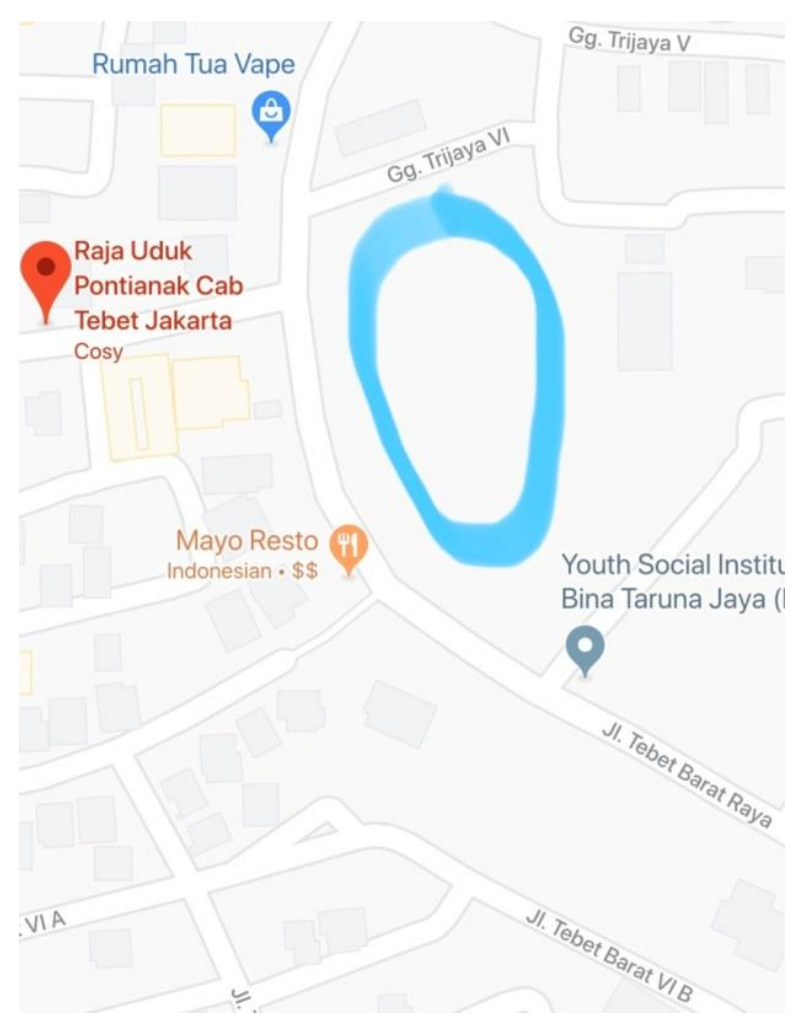

Fig. 1: Location where poor women live in Tebet area

Poverty culture can be seen in the way of life developed by poor people living under these conditions. This culture can be explored in urban and rural slum areas, which are both adaptations and reactions of the poor to their marginal position in class-stratified, highly individualistic societies, and characterized by capitalism [3].

Economists used a Gini Ratio or Gini Index measurement which compares the percentage of people whose control on resources to the percentage of income they receive. Small Gini ratio 
shows low inequality and, conversely, large Gini ratio shows high inequality. The latest Gini Ratio data from the Central Bureau of Statistics (BPS) was 0,384 (September 2018). In addition, Gini ratio never reached the highest rate in 2011, i.e. 0,410 [4]. Based on the observation, such inequality was strongly felt by women, and it happened to poor women. Poor women are women who live, inhabit and work in places that are not feasible compared to their surrounding environment. There are 10\% of workers in the world, earning 1,9 US\$ per day, and it is equivalent to IDR 770.000,- per month. In addition, most of them are women. The reason why women experience this inequality is probably due to gender inequality. Gender inequality has caused women to earn a low income, underappreciated and not equally treated at work [5]. Based on this elaboration, it is clear that there is a correlation between women and poverty. The percentage of poor people released by Central Bureau of Statistics (BPS) in September 2018 is $9,66 \%$. Moreover, per capita income of people living on the poverty line is IDR 410.670 ,- per month, of which $7,02 \%$ of them live in cities. During observation, such women experienced a lack of nutritious food and clean clothing, and did not have proper resting place and cleaning facilities. As a result, those women usually looked dull, old before their normal time and they had thin body or fat because they consumed junk food. Their skin was mostly dark due to the burning heat of the sun.

However, there are currently no more poor people found in tattered and dirty clothes. This may be the fact that cheap used clothes imported from China can now easily be bought at Senen Market at a price of 10 thousand rupiah. The clothes commonly still look good, nice and colorful. Nevertheless, from the experiments conducted by the author, it caused itching for those who are not accustomed to using it, even though it has been soaked in boiling water during washing. Another thing obtained from in depth research was the source of hijab (headscarves) worn by these slum women. Tebet, since Pilkada (regional governor election) two years ago, has become the basis of certain organization which emphasizes certain religious symbols. Accordingly, wearing hijab became a 'mandatory' for women rag pickers entering the housing environment. They were given a hijab and required to wear it. 


\section{International Journal of Arts and Humanities}

ISSN: 2581-3102

Volume: 04, Issue: 04 "April 2020"

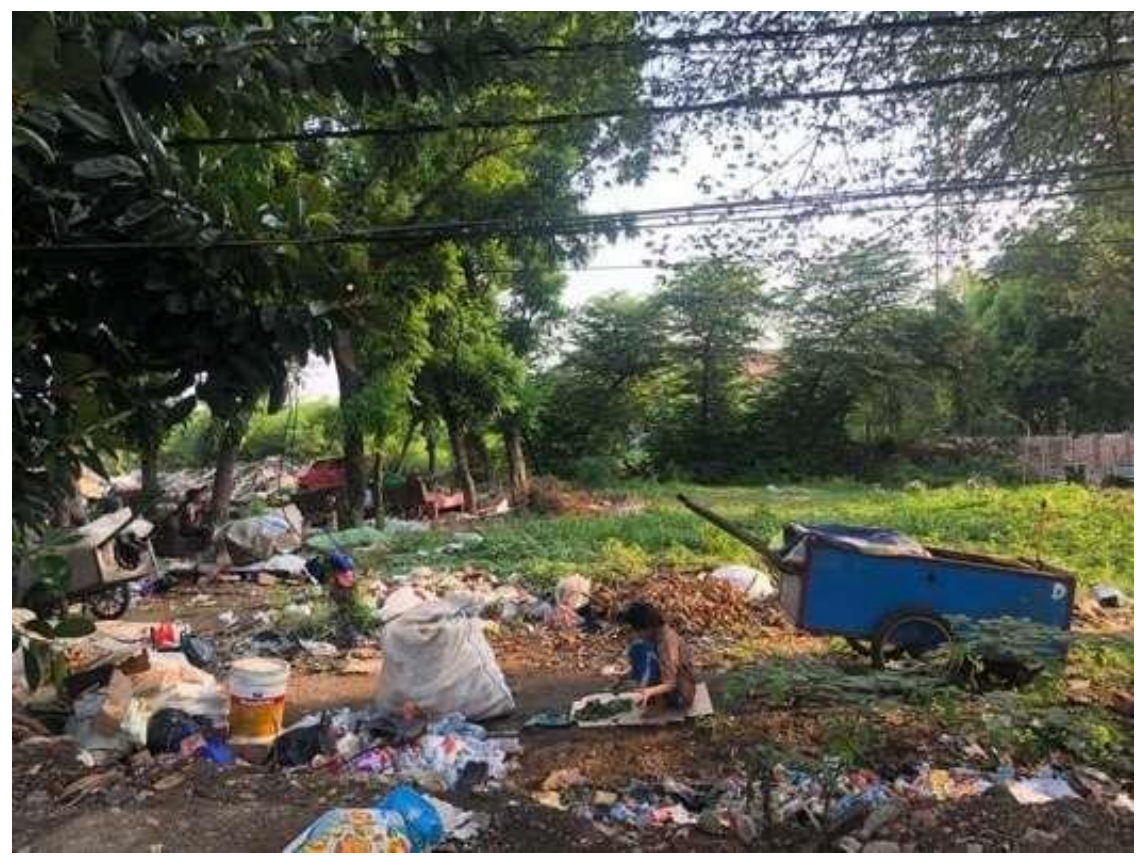

Fig. 2: A poor woman chopping vegetables

Poor women often worked as beggars, rag pickers and buskers. This happened because they were less educated or did not get any chance to get better jobs. They made a living for their families with a minimum daily income. Concern to poor women has aroused feelings of expression, and become an inspiration to create paintings. The instrument of life and its support system in the slums was a culture of poverty which was an adaptation as well as the reaction of the poor to their marginal position. Poor women are women who live, inhabit and work in places that are not properly feasible compared to their surrounding environment. Making their own food with the raw materials taken from unsold material discharges at the nearest market, Tebet Barat (western Tebet) and PSPT markets (eastern Tebet), was a clear reaction to their marginal position. With IDR 410.670,- per capita income per month, it is not possible for them to be able to buy even the cheapest food from stalls or roadside traders since they have to spend IDR 13.000.- for buying gado-gado (Indonesian vegetables salad with peanut sauce) and rice and it will be IDR 20.000,if they added a boiled egg and a bottled tea. Therefore, they had to cook on their own to fulfill their stomach need.

\section{METHOD}

The painting art works were done in a realism style because painting the poor with this style had been done by previous painters, such as William Hogarth (1697-1764), Nikolay Alekseyevich Kasatkin (1859-1930) and Luigi Nono (1850-1918). Besides being a painter, Hogarth was a 


\section{International Journal of Arts and Humanities}

ISSN: 2581-3102

Volume: 04, Issue: 04 "April 2020"

social critic and cartoonist born from a lower class in London city. He was popularly known as a realist painter who described social situation and real life at that time [6]. Many of his paintings depicted many tramps, prostitutes, public gambling, poverty, and the contrast life between the rich and the lower classes in England. In "Night" (1736) painting, Hogarth described the situation of the lower classes in London city when it started at dusk. It could be seen that people lighted a campfire to warm their body. Some children and mothers slept on carts and stores terraces. In his paintings, Hogarth illustrated the contrast in better classes from behind a bright window.

Kasatkin was one of the pioneers in painting with Social Realism style in Russia. In 1883 he worked for the State by creating an almanac and contributed to the compilation of the encyclopedia "Russian History in Pictures". After becoming a member of the State Academy of Art, he then made a series of works inspired by 1905 Revolution. His paintings depicted miners, "The Poor, Picking up Pieces of Coal" (1894) and "A Worker's Family" (1890). Then, in 1971, they were made as a series of stamps by the Russian Government.

Luigi Nono, an Italian painter, was famous for the scenes in his paintings depicting poor people. He described everyday life carefully so that his work later became very influential in his day. Nono depicted painful and poignant scenes, such as the burial of a poor child or a homeless mother and her child sleeping under the church door. In the art work of "Study of Abbandonati", Luigi Nono depicted a beggar and his child sleeping on the roadside, in the corner of a building. The painting was dominantly light brown in color to illustrate the bitter situation occurring to the beggar.

Based on the review of the three painters' works, it can be stated that the poor can be represented in various ways, i.e. by describing the type of work chosen, the atmosphere of their house/place while resting, the clothing they wear, activities outside the home with neighbors, or show that they are beggars and trash people explicitly in the painting, complete with moods depicted from the look on their face. There was indeed an attempt by the painters to make the atmosphere dramatic by showing the work or activities of the depicted figures or to show clothes worn look shabby as the efforts made by Luigi Nono and William Hogarth. Nevertheless, there are also paintings which show poverty in an unexplained manner, but through natural portrayals as shown by Kasatkin in “A Worker's Family”.

By knowing this fact, we can learn that the poor can be described by showing how they make a living. Such as the activities of women pulling garbage carts in Tebet, becoming rag pickers, being buskers, and selling newspapers. Moreover, it can also be seen from their daily activities such as a mother who took her children to play on the sidewalk, women holding children while scavenging trash and washing used mineral water bottles. These activities could be seen naturally 


\section{International Journal of Arts and Humanities}

ISSN: 2581-3102

Volume: 04, Issue: 04 "April 2020"

without dramatization, but still we could feel the nuances of poverty there. Without showing a sad face in the painting, the paintings could depict poor people from the activities they do every day.

As in dressing, with the influx of ex-imported used clothing from China, these poor people could have colorful clothes. Hence, it was difficult to describe the poor in Tebet sub district by only relying on the depiction of dirty clothing since there were many cheap colorful clothes worn by women pulling garbage carts. Accordingly, the strategy for describing life by depicting how they earned a living and daily activities naturally was the most proper way to describe poor women in Tebet sub-district. Furthermore, such strategies were used in creating the art works in this paper.

\section{RESULTS AND DISCUSSION}

Realism is a painting which must meet certain rules to convince the viewers about the paintings' accuracy and equitableness. The rules include: figures depicted besides being true as its reality, the gestures and the movements must look natural, proper and reasonable, and the figures should fit to fill the space in the painting field. Such suitability and accuracy also apply to the composition of the background and the foreground. If there is a transition involving the background and foreground, for example there is a river bend in the picture/photograph, then the transition must be described smoothly. Thus, it may provide a sense of continuous space. Moreover, also in the formation of shadows on objects, the colors must be chosen in such a way that the lighting looks convincing. In realism, the details of the objects must be described carefully, so that the viewers can get a complete description of the location of the event in the picture/photograph or painting [7].

From the definition of realism given by Fuchs, it can be elaborated that a realism painting must fulfill these elements, i.e. (1) Equitableness, which is depicted by humans; then the gestures of the figures must look reasonable; (2) Natural, humans are described as they were moving; so their movements can look natural; (3) Detailed, the object must be described in detail; (4) Proportional, humans and objects must fill the image space proportionally to make it look fit right or appropriate; (5) Right composition, the composition between background and foreground must be precise and both transitions should look smooth; (5) Lighting and supporting shadow. Lighting and shadow must be considered by choosing coloring method in such a way that supports the depicted figures. Lighting and shading actually give suggestions about time when it is describing open spaces or involving the shadow of the sun; and (6) Environment, the detail in the environment surrounding the figure must be made carefully, so that the viewers can imagine the location of the event depicted in the painting. If these rules are followed, then the painting created will be able to convince the viewers since because the paintings look natural and similar to the real situation. Fuchs exemplified the painting "The Raising of Lazarus" (1455) made by 


\section{International Journal of Arts and Humanities}

ISSN: 2581-3102

Volume: 04, Issue: 04 "April 2020"

Albert Ouwater as a realism painting which fulfill all these rules. Fuchs stated that Ouwater had eventually succeeded in describing the emergence of Lazarus from the grave, so it looked very convincing.

Furthermore, in raising poor women theme into painting art media, the author used photo realism style. Photo realism is a school in painting which requires that the object being painted is a reality or a reality existing in nature or society through the help of photography. Artists of photo realism will commonly edit, add and manipulate the results of their photos before they are painted. Editing and manipulating the photos aim to create a dramatic effect as desired by the painter. Meanwhile, the similarity level of photo realism techniques is almost the same as reality [8]. In addition, Richard Estes stated that photo realism is a painting made based on photo examples. The results of the paintings based on the results of the photo are mostly better because than the original since the paintings can be beautified with colors, scratches, strokes and textures by the hands of the artists; hence the paintings become good art works [9].

At the beginning of the design, the painter started with research. The research technique carried out was active participation technique by observing the lives of women in the locations where poor women worked, which was widely spread in Tebet. The research was conducted by interviewing and photographing beggars, rag pickers, newspaper sellers and buskers who were doing their activities on the streets and places they worked at. The works of painting began to be made after the desired photo obtained. Based on the photo, a sketch was made referring to the object in the photo. The selected photo would be a reference in sketching. Then, the sketch was created using pencil media by copying objects from the picture or drawings or photographs. Sketch ought to be made in detail by making grid lines to enlarge the image. Thus, the size matched the canvas used. Accordingly, the accuracy of the object position could be obtained. This was the initial process in designing a painting before it was executed in more detail steps.

Painting on canvas was done after the sketch has been finished. The first thing to start was to give a touch of natural color on the canvas area. After the entire painting field had been given a natural color, a mixture of white and brown color, the first coloring was the background. The color of the main object and background had to be contrasted so that the object looked prominent. In the second stage, after the first coloring had finished, a repetition was done by making the second coloring. This second coloring was to give a touch of dark light according to the photo example. Then, the third stage coloring is the last coloring aiming to correct any deficiencies in each field. After the paintings have been finished, the paintings were not framed since there has been an active campaign to reduce waste and to save trees, and the current trend is frameless paintings in accordance with contemporary art trends. 
Mikke Susanto said that color can be defined as vibrations or waves received by the human sense of sight that comes from the emission of light through an object. Color is one of the most important parts in creating a painting. Primary colors are colors that cannot be formed by other colors and can be used as a mixing basis to obtain other colors, these colors include: red, yellow, and blue. Secondary color is the result of mixing at least two primary colors. Secondary colors include orange, violet, and green [10].

Sulasmi Darmaprawira W.A. added that visual perception affected brain's interpretation on a stimulus received by eyes. Colors certainly can affect human emotions and describe a person's feeling (heart). In addition, everyone has different color taste, so it shows that color is influenced by human's emotions [11]. The dominant colors used in this study of creating such art works were yellow, orange, green and brown. Yellow symbolizes brightness, life, victory, excitement, and warmth. Orange has the meaning and nuances of warmth, enthusiasm, friendship, business achievement, career, success, mind health, justice, endurance, joys, and something which grows. Then, green color is associated with plants, something that lives and develops. The character of green is fresh, young, alive, growing, and is more neutral. Brown color has meaning and nuances indicating friendship, special events, earth, materialistic thinking, reliability, and peace [12].

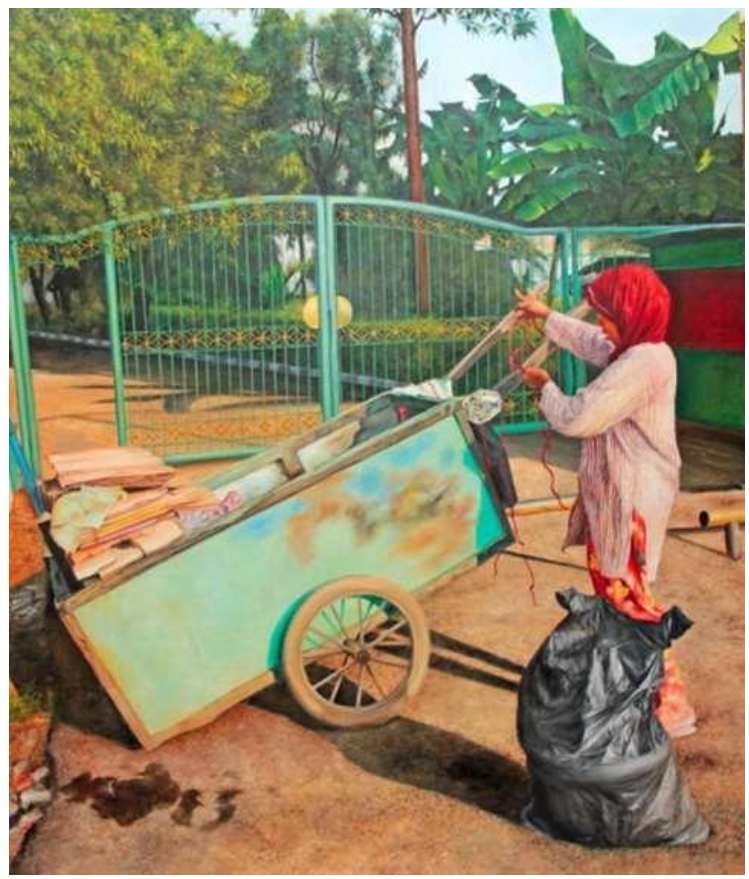

Fig. 3: "Semangat" ("Spirit"), $100 \mathrm{~cm}$ x $120 \mathrm{~cm}$, oil paint on canvas, 2019

The colors used in the art works produced were naturally equated with the original color without any addition. The colors of Tebet area were beautifully green and the appearance of poor women 
wearing colorful cheap or given clothes. The results of painting looked beautiful and lovely because they were supported by bright colors. Color could not hide the pain and suffering experienced by poor women as the paintings depicted the reality. For the objects, sharp colors were used to make them stand out, while the background colors used the vague ones. For the face, hands and feet parts, a mixture of green, yellow, brown, red and white colors were used to give the impression of fatigue after days exposed under the sunlight. The colors for poor women's clothing were a bit dull, using a mixture of white, black and brown. Overall, this works visualized bright colors because they depicted the struggle of poor women in the blazing daylight to make a living and to continue their life. During the period of 2017 - 2019, there were 29 painting art works produced from studies of the poor in Tebet area. This article discusses only two works representing the figures and characters of poor women (Fig. 3 and 4).

The painting art work in Fig. 3 entitled "Semangat" displayed a middle-aged woman, as painting object, picking a used cardboard using a cart. She looked always passionate, full of spirit and enthusiasm to start her job from early morning to night. This painting has $100 \mathrm{~cm}$ x $120 \mathrm{~cm}$ size in vertical form. The background of Tebet housing complex was shown to be cool as there were many trees which were green, beautiful and shady. The colors used were dominated by reddish brown which reflected the color of the road, used cardboard and also clothes worn by the rag pickers woman. The woman was wearing a red hijab on her head and pink batik pants. In addition, the cart was colored with light green and the tire wheels that should have been black had faded to brown. Next to the woman there was a black plastic bag. This painting was presented in order to make to the viewers give appreciation to many female rag pickerss going around in every big city. 


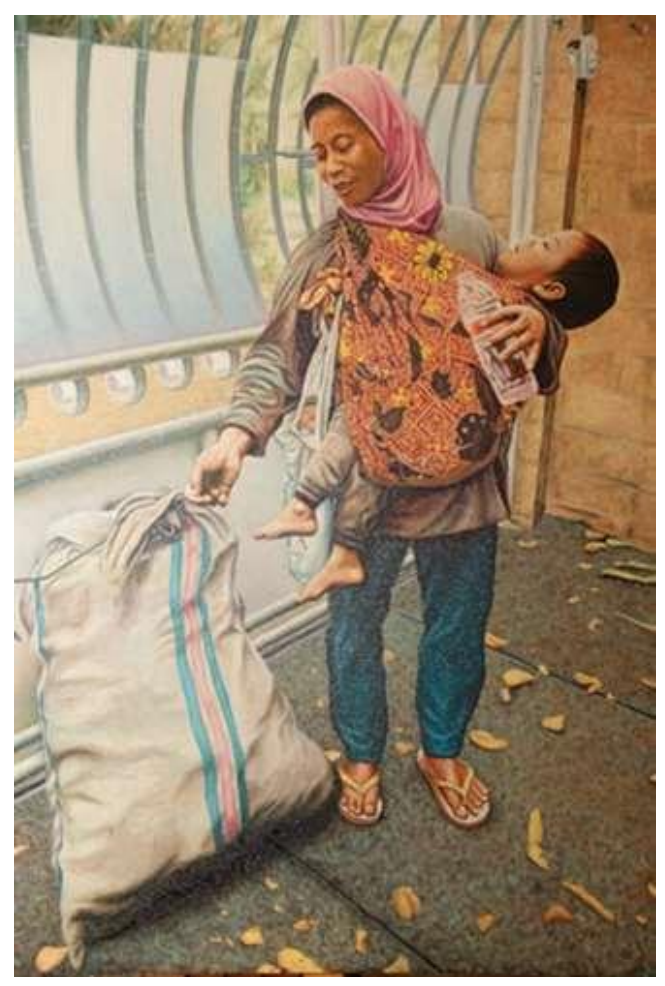

Fig. 4: "Tegar" (resilient), $100 \mathrm{~cm}$ x $120 \mathrm{~cm}$ oil paint on canvas, 2019

A painting art work in Figure 4 entitled "Tegar" shows a woman holding a child who was sleeping soundly. The mother tried to lift a plastic bag filled with various thrown items. Every day the mother always tried to find and obtain used goods which were still worth to sell in trash can or on streets. The mother was wearing a pink hijab, a light brown long-sleeved top and blue trousers. She was trying to lift a huge plastic sack, bigger than her body, which was almost full. The background was a white fence with a cement floor from one of the residents in a housing complex. This painting depicts the struggle of the mother who always tried to be tough, resilient, strong and patient and tireless for her daily survival.

\section{CONCLUSION}

The objects of poor women were chosen as inspiration to create paintings art works because the level of difficulty was greater and more attractive than men. It was more difficult to approach poor women as the object since the culture of shame and greater self-esteem in women. Raising the lives of poor women is very important and necessary to be made as a creation of art works as it reflects the real conditions which occur in society.

Poor people can be described by showing how they make a living. Like the activities of women who work in informal sector. Their activities can be seen naturally without dramatization, but we 
International Journal of Arts and Humanities

ISSN: 2581-3102

Volume: 04, Issue: 04 "April 2020"

still feel the nuances of poverty there. We can depict poor people from their daily activities without even showing a sad face in paintings.

By using the definition of realism from Fuchs, the paintings must be able to convince the viewers since they are proportionally depicted in detail. In the process of realism, this paper used photos as references in creating painting art works. However, it is different from Richard Estes, that by using photography 'seeing' the beauty of New York City and with that he 'looking up' to record the skyscraper towers. This article, in contrast, did 'seeing' the slums of Tebet sub-district and with that the painter 'looking down' to record poor women who made a living in a corner of Tebet.

\section{REFERENCES}

[1] Parsudi Suparlan, Kemiskinan di Perkotaan, Bacaan untuk Antropologi Perkotaan (Poverty in the Cities, Reading for Urban Anthropology): Yayasan Obor Indonesia, 1984, p. 12.

[2] Thomas Hidya Tjaya, Enigma Wajah Orang Lain (Enigma in Another People Faces): KPG, 2012, p. 49.

[3] Joanne Grenspun, Chuck Close: The Museum of Modern Art, 1998, p. 29-31.

[4] Bustanul Arifin, Ketimpangan Setelah Otonomi Daerah (Inequality After Regional Autonomy): Tempo Magazine, $23^{\text {rd }}$ Edition, Jun 2019, p.67.

[5] Fancesca Rhodes, Anam Parvez dan Rowan Harvey, Why the Majority of the World's Poor are Woman: Oxfam International, March 2017.

[6] Carlo Ludovico Ragghianti, Masterpieces of the World's Great Museums: The Hamlyn Publishing Group, 1988, p. 114.

[7] R. H. Fuchs, Dutch Painting: Thames and Hudson Ltd., 1989, p. 20.

[8] Dharsono Sony Kartika, Kreasi Artistik Perjumpaan Tradisi Modern dalam Paradigma Kekaryaan Seni (Artistic Creations Meelting Point of Modern Traditions in the Artwork Paradigm): Citra Sain, 2018, p. 88.

[9] John Arthur and Richard Estes, A Conversation: Museo Thyssen-Bornemisza, 2007, p. 102.

[10] Mikke Susanto, Diksi Rupa Kumpulan Istilah dan Gerakan Seni Rupa (The Art Diction Collection of Terms and Movement of Fine Arts), DictiArt Lab, 2011, p. 433.

[11] W.A. Darmaprawira and Sulasmi, Warna Teori dan Kreativitas Penggunaannya (Color Theories and Applied Creativities): ITB Press, 2002, p. 30.

[12] Sadjiman Ebdi Sanyoto, Nirmana Elemen-elemen Seni dan Desain (Art and Design Dimension Elements): Jalasutra, 2009, p. 32. 